\title{
Main controlling factors and enrichment area evaluation of shale gas of the Lower Paleozoic marine strata in south China
}

\author{
Xian-Ming Xiao ${ }^{1} \cdot$ Qiang Wei $^{1,2} \cdot$ Hai-Feng Gai ${ }^{1} \cdot{\text { Teng-Fei } \mathrm{Li}^{1,2}}^{1, \text { Mao-Lin Wang }}{ }^{1,2}$. \\ Lei $\operatorname{Pan}^{1,2} \cdot$ Ji Chen ${ }^{1,2} \cdot$ Hui Tian ${ }^{1}$
}

Received: 11 May 2015/Published online: 3 October 2015

(C) The Author(s) 2015. This article is published with open access at Springerlink.com

\begin{abstract}
The Lower Paleozoic shale in south China has a very high maturity and experienced strong tectonic deformation. This character is quite different from the North America shale and has inhibited the shale gas evaluation and exploration in this area. The present paper reports a comprehensive investigation of maturity, reservoir properties, fluid pressure, gas content, preservation conditions, and other relevant aspects of the Lower Paleozoic shale from the Sichuan Basin and its surrounding areas. It is found that within the main maturity range $\left(2.5 \%<\mathrm{Eq} R_{\mathrm{O}}<3.5 \%\right)$ of the shale, its porosity develops well, having a positive correlation with the TOC content, and its gas content is controlled mainly by the preservation conditions related to the tectonic deformation, but shale with a super high maturity $\left(\mathrm{Eq} R_{\mathrm{O}}>3.5 \%\right)$ is considered a high risk for shale gas exploration. Taking the southern area of the Sichuan Basin and the southeastern area of Chongqing as examples of uplifted/folded and faulted/folded areas, respectively, geological models of shale gas content and loss were proposed. For the uplifted/folded area with a simple tectonic deformation, the shale system (with a depth $>2000 \mathrm{~m}$ ) has largely retained overpressure during uplifting without a great loss of gas, and an industrial shale gas potential is generally possible. However, for the faulted/folded area with a strong tectonic deformation, the sealing condition of the shale
\end{abstract}

Xian-Ming Xiao

xmxiao@gig.ac.cn

1 State Key Laboratory of Organic Geochemistry, Guangzhou Institute of Geochemistry, Chinese Academy of Sciences, Guangzhou, Guangdong 510640, China

2 University of Chinese Academy of Sciences, Beijing 100049, China

Edited by Jie Hao system was usually destroyed to a certain degree with a great loss of free gas, which decreased the pressure coefficient and resulted in a low production capacity. It is predicted that the deeply buried shale $(>3000 \mathrm{~m})$ has a greater gas potential and will become the focus for further exploration and development in most of the south China region (outside the Sichuan Basin).

Keywords Lower Paleozoic shale gas · Maturity · Main controlling factors $\cdot$ Tectonic deformation

\section{Introduction}

Within the Lower Paleozoic marine strata in south China, two sets of organic-rich Lower Silurian and Lower Cambrian shales are widely developed (Liang et al. 2008, 2009; Nie et al. 2009; Zou et al. 2010), covering areas of up to $42 \times 10^{4} \mathrm{~km}^{2}$ and $(30-50) \times 10^{4} \mathrm{~km}^{2}$, respectively (Zou et al. 2010). The predicted geological resource potential of shale gas $(<4500 \mathrm{~m})$ is $17 \times 10^{12} \mathrm{~m}^{3}$ and $35 \times 10^{12} \mathrm{~m}^{3}$, respectively. Their sum accounts for about $39 \%$ of the total onshore shale gas resource (Zhang et al. 2012), indicating a huge potential for shale gas exploration and development.

In recent years, shale gas exploration in the Lower Paleozoic marine strata in south China has been carried out actively. Great progress has been made in the Sichuan Basin where the tectonic deformation is relatively simple. Industrial shale gas production has been achieved from some areas, such as the Weiyuan, Changning, and Fuling blocks (Huang et al. 2012a, b; Guo and Liu 2013; Li et al. 2014; Wang et al. 2013c; Wang 2013). Especially in the Jiaoshiba area of the Fuling Block, initial gas production of $(10-50) \times 10^{4} \mathrm{~m}^{3} / \mathrm{d}$ has been reported for most tested 
wells, and the average yield of well JY1 in the first year was $6 \times 10^{4} \mathrm{~m}^{3} / \mathrm{d}$ (Guo and Zhang 2014). The Jiaoshiba area is planned to the first commercial development demonstration base for shale gas in China. However, outside the Sichuan Basin, the gas content in shale is generally low, most of the tested wells do not reach an industrial capacity (Ma et al. 2014; Yi and Zhao 2014; Zhou et al. 2014a), and the exploration and development of shale gas still meets with challenges such as complicated structural conditions, poor resources, and variable geography (Wang 2013).

Based on the geological and geochemical characteristics of the Lower Paleozoic shale in south China, the present paper mainly focuses on the reservoir properties of the very high maturity shale, preservation conditions controlled by tectonic deformation, and their influence on shale gas content. The main controlling factors of shale gas content and the evaluation criteria for a favorable shale gas play are discussed. The purpose is to provide guidance for further exploration and development.

\section{Geological characteristics of the Lower Paleozoic shale}

There are a few similar geological and geochemical characteristics between the North America shale and the Lower Paleozoic shale in south China, such as the TOC (total organic carbon) content, organic type, shale thickness, mineral composition, brittle mineral content, Poisson's ratio, and Young's modulus (Li et al. 2013b; Wang et al. 2012a, b; Tu et al. 2014). This is the main basis for a huge shale gas potential of the Lower Paleozoic shale in south China predicted by scholars and organizations (Zhang et al. 2012; EIA 2011, 2013). However, the Lower Paleozoic shale is characterized by very high maturity and strong tectonic deformation (Nie et al. 2011; Wang et al. 2009b; Xiao et al. 2013), which shows an obvious difference from the North America shale (Table 1). Taking the southern area of the Sichuan Basin as an example (Fig. 1), the burial history and thermal maturation evolution of the lower Paleozoic strata can be largely divided into four stages:

Stage 1 (from Cambrian to Silurian): Marine strata with a thickness of 2500-3000 m were deposited. The Lower Cambrian and Lower Silurian shales underwent an early maturation at temperatures of $80-90{ }^{\circ} \mathrm{C}$ and $50-60{ }^{\circ} \mathrm{C}$, respectively. Their $\mathrm{Eq} R_{\mathrm{O}}$ (equivalent vitrinite reflectance) values became $0.6 \%$ and $0.4 \%$, respectively.

Stage 2 (from Devonian to Carboniferous): The strata underwent uplifting and erosion. The upper Silurian was generally eroded, with an eroded thickness of 500-1000 m.

Stage 3 (from Permian to Early Cretaceous): Deposition began from Permian, speeded up in Jurassic, and continued up to Early Cretaceous, with a total thickness of 5000-6000 m. During Early Cretaceous, the burial depth of the Lower Cambrian and Lower Silurian shales reached about 8000 and $7000 \mathrm{~m}$, corresponding to a maximum temperature of $250-260{ }^{\circ} \mathrm{C}$ and $220-230{ }^{\circ} \mathrm{C}$, respectively. The shales experienced strong thermal maturation and reached a very high maturity, with an $\mathrm{Eq} R_{\mathrm{o}}$ value of $2.5 \%$ (the Lower Silurian shale) and 3.5\% (Lower Cambrian shale).

Stage 4 (from Late Cretaceous to present): Influenced by the tectonic deformation of the late Yanshanian-Himalayan movements, this area was uplifted and the strata were eroded strongly from the Late Cretaceous. The eroded thickness was up to 2500-4000 m generally.

For the Yangtze region outside the Sichuan Basin, the burial history and thermal maturation evolution of the Lower Paleozoic strata are basically consistent with the Sichuan Basin, but the uplifting occurring during the late Yanshanian-Himalayan period was earlier and the structural deformation was stronger, with an obvious regional differentiation (Mei et al. 2010). With a background of general strong uplifting, the intense tectonic deformation resulted in fold deformation and fault cutting, forming rather complex structural patterns (Hu et al. 2014; Tang and Cui 2011; Yan et al. 2000). For example, trough-like

Table 1 Main differences between the Lower Paleozoic shale in south China and the North America shale

\begin{tabular}{|c|c|c|c|}
\hline Feature & Sichuan Basin & Outside the Sichuan Basin & North America \\
\hline Age & $\begin{array}{l}\text { Lower Silurian and Lower } \\
\text { Cambrian }\end{array}$ & Lower Silurian and Lower Cambrian & $\begin{array}{l}\text { Devonian, Carboniferous, and } \\
\text { Cretaceous }\end{array}$ \\
\hline Present burial depth, m & $2000-6000$ & $1000-6000$ & $2000-4000$ \\
\hline $\begin{array}{l}\text { Burial depth with industrial } \\
\text { shale gas production, } m\end{array}$ & $2000-3500$ & No data & $1500-3000$ \\
\hline Maturity $\left(R_{\mathrm{o}}\right.$ or $\left.\mathrm{Eq} R_{\mathrm{o}}\right), \%$ & $2.5-3.5$ & $2.5-3.5$ & $1.0-2.5$ \\
\hline Tectonic deformation & $\begin{array}{l}\text { Strongly uplifted with an eroded } \\
\text { thickness of } 2000-4000 \mathrm{~m}\end{array}$ & $\begin{array}{l}\text { Strongly uplifted, folded, and faulted with } \\
\text { an eroded thickness of 3000-5000 m }\end{array}$ & $\begin{array}{l}\text { Simply uplifted with an eroded } \\
\text { thickness of } 1500-3000 \mathrm{~m}\end{array}$ \\
\hline
\end{tabular}



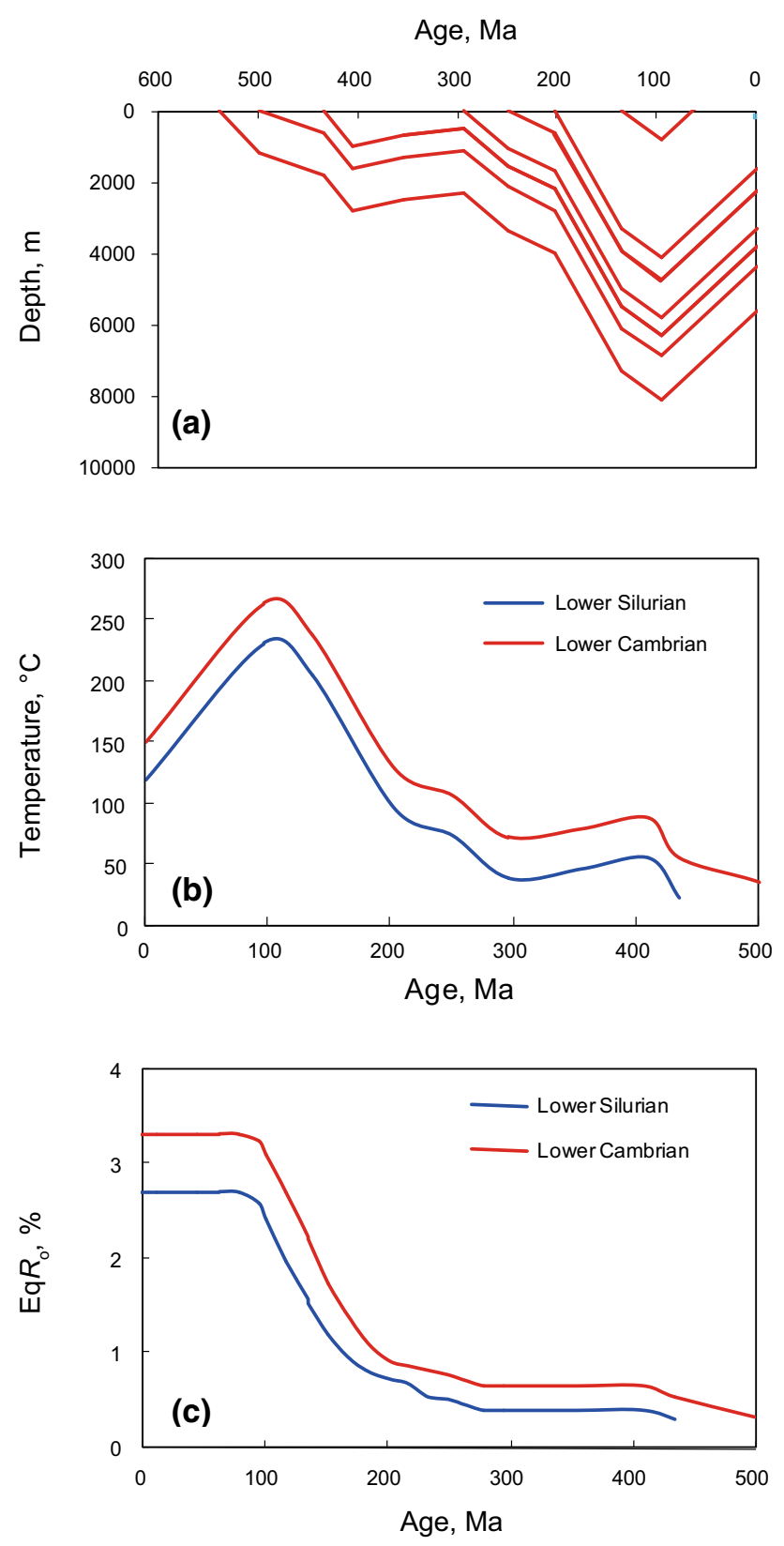

Fig. 1 Burial history of strata (a), paleogeotemperature of Lower Cambrian and Lower Silurian (b), and maturity evolution (c) from well Pan 1 in the southern area of the Sichuan Basin

folds (wide-gentle anticline and narrow-steep syncline) developed widely in the Zhaotong area to the south of the Sichuan Basin (Wang 2013). The structural styles are more complex in the southeast Chongqing area to the east of the Sichuan Basin. From the northwest to southeast, the structure changed gradually from comb-like folds (widegentle synclines and narrow-steep anticlines) to trough-like folds, and transitional folds composed of wide-gentle synclines and anticlines developed in the middle area $(\mathrm{Li}$ et al. 2012; Wei et al. 2014) (Fig. 2).
Maturity not only controls the gas generation of shale, but also affects the reservoir properties (Curtis et al. 2012; Fishman et al. 2012; Loucks et al. 2009; Mastalerz et al. 2013; Modica and Lapierre 2012; Valenza et al. 2013). The maturity of the Lower Paleozoic shale in south China is generally rather high, but it varies significantly in different regions (Nie et al. 2009). The Lower Cambrian and Lower Silurian shales have Eq $R_{\mathrm{O}}$ values of, respectively, $2.7 \%-$ $6.2 \%$ and $1.9 \%-3.8 \%$ in the whole Yangtze region (Cheng and Xiao 2013), and 2.5\%-3.5\% and $2.4 \%-$ $3.2 \%$ in the Sichuan Basin (Wang et al. 2009a; Zou et al. 2014). Shale generally has a quite low porosity when it has evolved to the dry gas stage $\left(R_{\mathrm{o}}>2.0 \%\right)$ (Wang et al. 2013a), but its reservoir properties still change with further increasing maturity (Chen and Xiao 2014). Substantial uplifting and strata denudation reduce the temperature and pressure of a shale system, which will lead to an increase in its fluid pressure coefficient if the system is ideally confined (Zhou et al. 2014b). Faults and folds may damage the sealing condition of a shale system, and as a result a great loss of shale fluids occurs with a significant reduction of the fluid pressure coefficient (Hu et al. 2014; Guo 2014). These geological processes have a great impact on shale gas contents and yields, and become the primary concern for the shale gas exploration and development of the Lower Paleozoic strata in south China.

\section{Maturity and gas content of shale}

\subsection{Influence of maturity on shale porosity}

The relationship of maturity and gas contents in shale is mainly reflected by its impact on reservoir properties, which includes two diverging aspects: gas generation to form organic pores with an increase of total porosity, and compaction to reduce average pore size with a decrease of total porosity and permeability (Cander 2012; Curtis et al. 2012; Chalmers et al. 2012a; Mastalerz et al. 2013; Milliken et al. 2012, 2013). During burial history, continuous gas generation is of great significance to the enrichment of shale gas. On one hand, reservoir space will increase with a continuous formation of organic pores. On the other hand, continuously generated gas supplies a possible gas loss and balances a decrease of fluid pressure associated with the increase of free gas capacity caused by increasing burial depth, thus supporting the shale porosity (Milliken et al. 2013). When the burial depth is over the limit of gas generation, further burial will lead to a significant compaction, and a decrease of shale total porosity will occur due to the inevitable gas loss from the shale. Thus, the evolution of shale porosity has a close relationship with the gas generation. 

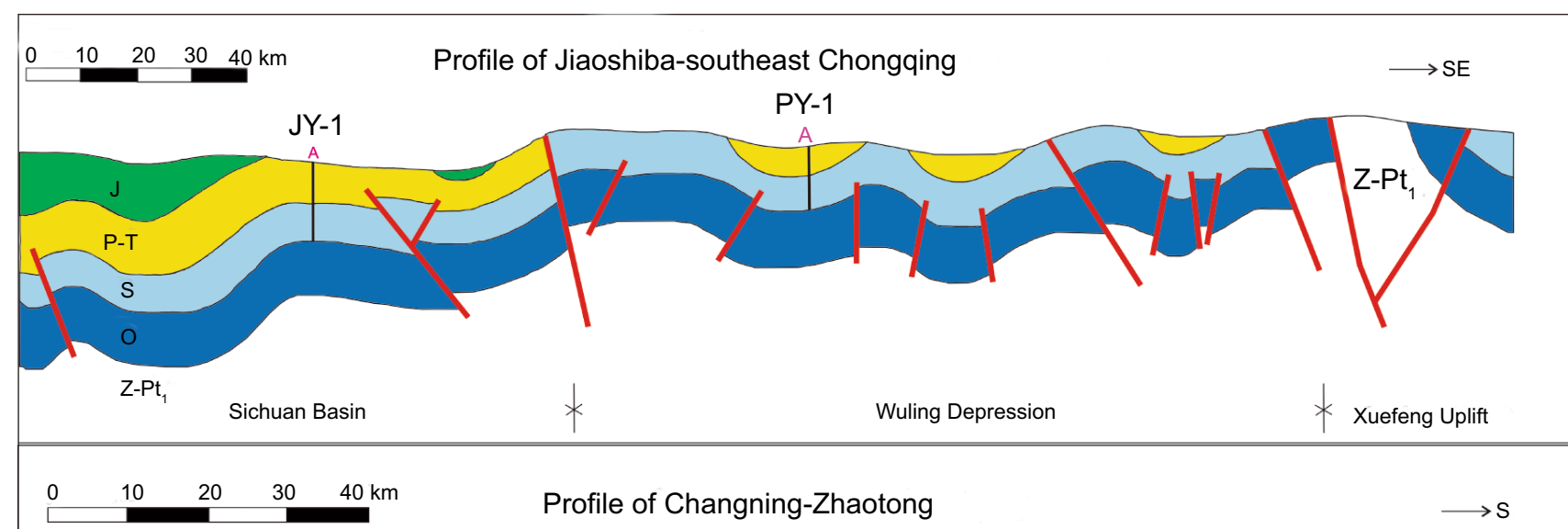

Profile of Changning-Zhaotong

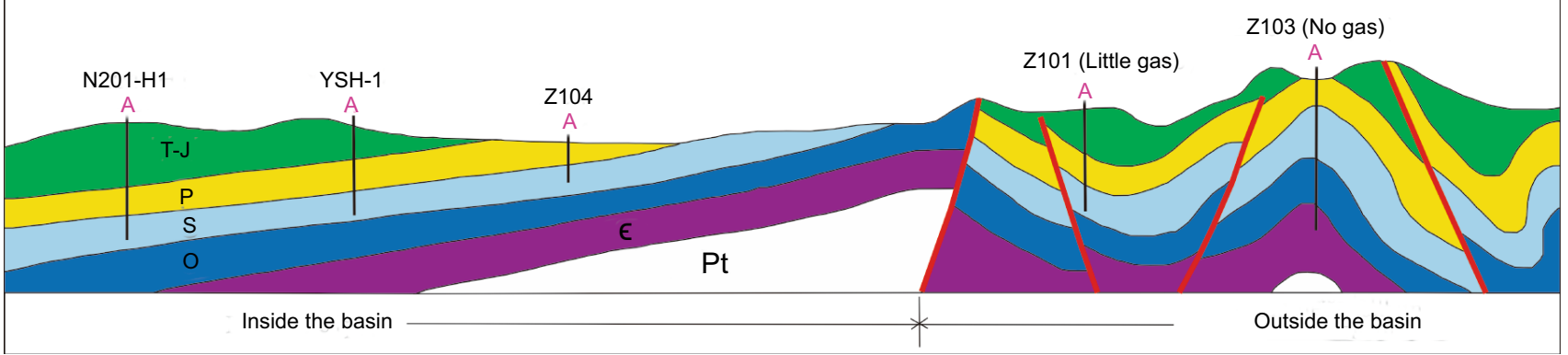

Fig. 2 Typical structural profiles across the Sichuan Basin and its surrounding areas (Modified after Guo 2014)

Using the hydrocarbon generation kinetics method, Cheng and Xiao (2013) simulated the hydrocarbon generation and evolution of the Lower Paleozoic shale in the Sichuan Basin, and suggested a general geological model for gas generation. According to their results, the main gas generation stage is within an $\mathrm{Eq} R_{\mathrm{O}}$ value range of $1.5 \%$ $2.5 \%$, and the gas generation limit occurs at an $\mathrm{Eq} R_{\mathrm{O}}$ value of about $3.0 \%$. Gas generated after $\mathrm{Eq} R_{\mathrm{o}}>2.5 \%$ accounts for about $10 \%$ of the total gas yield. This portion of gas would be important to the preservation of shale porosity in the very high maturity stage. Porosity data from the North America shale and the Lower Paleozoic shale of the southern area of the Sichuan Basin show an obvious decrease when $R_{\mathrm{O}}$ or $\mathrm{Eq} R_{\mathrm{O}}$ is over $3.0 \%$ (Wang et al. 2013a), implying that this relationship indeed exists in natural shale systems. Figure 3 further shows that shale porosity varies widely from $3 \%$ to $6 \%$ when $R_{\mathrm{o}}$ or $\mathrm{Eq} R_{\mathrm{o}}$ value is between $1.0 \%$ and $3.0 \%$, without a clear relationship with maturity, which reflects the combined effect of multiple factors (except for maturity), such as TOC content and mineral compositions on shale porosity (Curtis et al. 2010; Chalmers and Bustin 2008; Chalmers et al. 2012; Ross and Bustin 2009). When $R_{\mathrm{o}}$ or $\mathrm{Eq} R_{\mathrm{o}}$ is between $3 \%$ and $5 \%$, shale porosity varies within a narrow range, mainly between $2 \%$ and $4 \%$, having an obvious decreasing trend with increasing maturity.

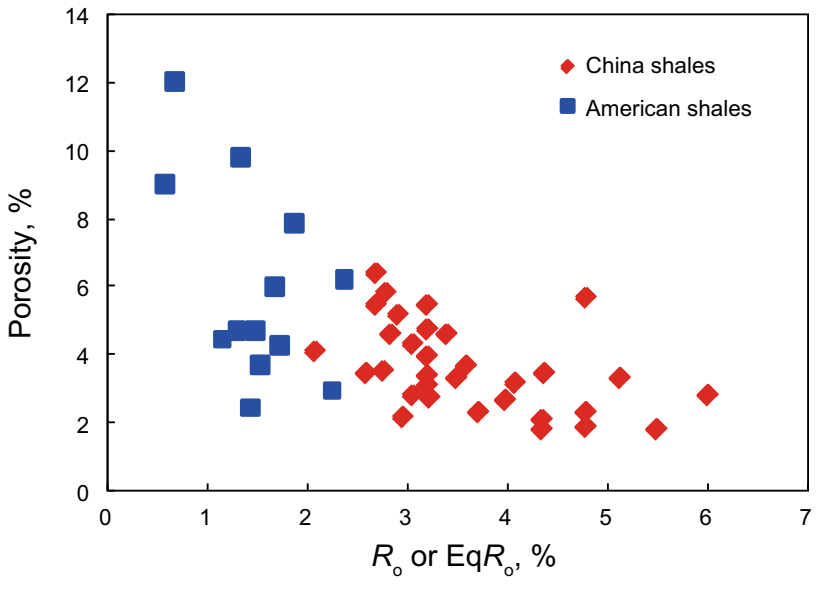

Fig. 3 Correlation between maturity and shale porosity (modified after Cheng and Xiao 2013, with some new data)

For shale with a very high maturity, inorganic matrix porosity is very low due to strong compaction. For instances, this value is approximately $1 \%$ for the Marcellus Shale $\left(R_{\mathrm{O}}=2 \%\right)$ (Milliken et al. 2013) and $1.2 \%$ $1.3 \%$ for the Lower Paleozoic shale $\left(\mathrm{Eq} R_{\mathrm{o}}=2.0 \%\right.$ $3.1 \%$ ) from the southern area of the Sichuan Basin (Wang et al. 2013a). Therefore, the development and evolution of organic pores becomes an important factor affecting shale 
porosity. According to the data from literature, shale porosity has a clear positive correlation with TOC content when TOC is within a definite range (Milliken et al. 2013; Pan et al. 2015; Tian et al. 2013; 2015; Wang et al. 2013a). However, this positive correlation will be changed or even reversed to be negative when TOC is very high, over this range (Milliken et al. 2013; Pan et al. 2015; Wang et al. 2013a). The TOC turning point occurs at about $5.6 \%$ for the Marcellus Shale (Milliken et al. 2013), $5.0 \%$ for the Lower Paleozoic shale from the southern area of the Sichuan Basin (Wang et al. 2013a), and $12 \%$ for the Upper Permian shale from the Lower Yangtze region (Pan et al. 2015). This is attributed to an easier compaction of organic nano-pores for shale with a higher TOC content than shale with a lower TOC content (Milliken et al. 2013; Wang et al. 2013a; Pan et al. 2015). Compaction not only reduces total porosity, but also changes pore structure significantly. For example, the Lower Cambrian shale from well HY1 has a significantly lower porosity than the Lower Silurian shale from well PY1 (both shales have a similar maturity) (Tian et al. 2013, 2015), but the former has much higher level of nano-pores $(<10 \mathrm{~nm})$ as compared with the latter (Fig. 4), which indicates that the compaction effect is more
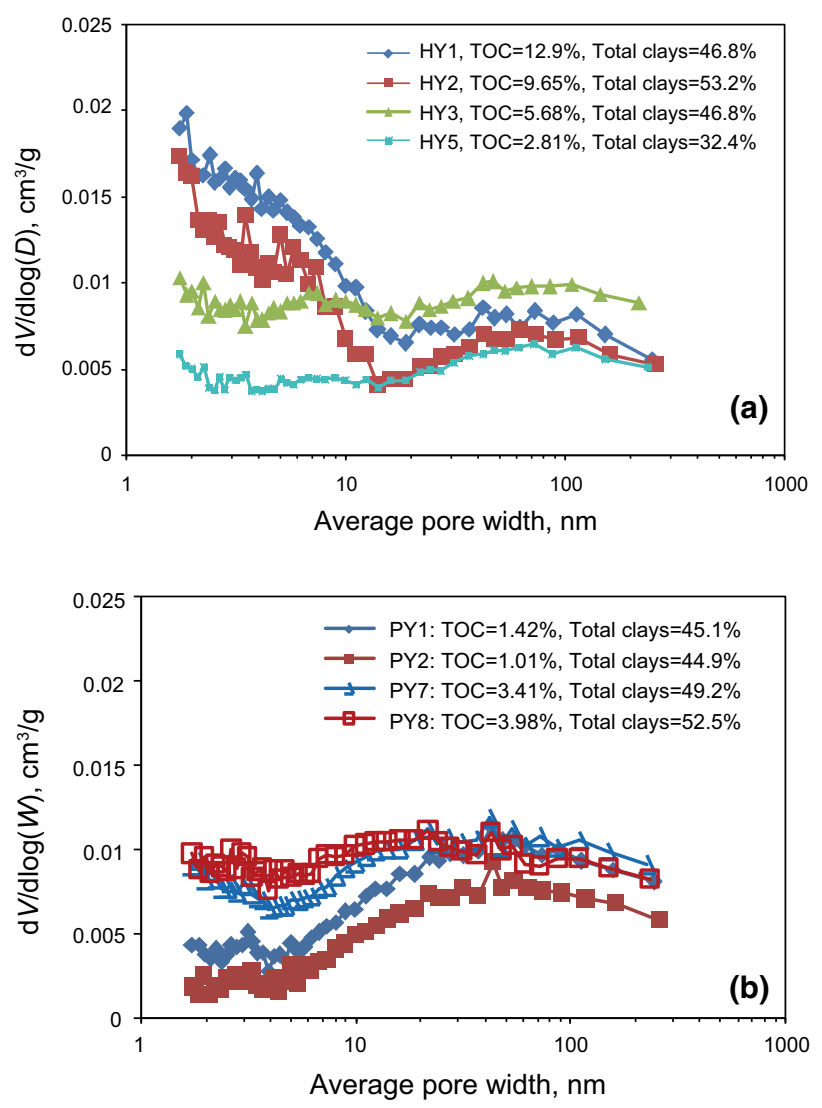

Fig. 4 Comparison of nano-pore structure between the Lower Cambrian shale from Well HY1 and the Lower Silurian shale from Well PY1 (simplified after Tian et al. 2015) evident for macropores and larger mesopores, resulting in a reduction of the average pore size and an increase of the micropore volume and specific surface area of the shale.

\subsection{Porosity evolution model of shale}

Based on the data from the Eagle Ford shale, Cander (2012) proposed an evolution model of inorganic matrix porosity and organic porosity in shale. According to his model, the inorganic matrix porosity significantly decreases with increasing burial depth up to $3000 \mathrm{~m}$. When the burial depth is over $3000 \mathrm{~m}$, the reduction of inorganic matrix porosity becomes less, but the organic pores start to develop and increase rapidly. The total porosity of shale does not change significantly within the range of 4000-5000 m. Combined with the gas generation evolution and porosity data of the Lower Paleozoic shale from the Southern China region, this model is modified and extended to a greater burial depth $(9000 \mathrm{~m})$ (Fig. 5). According to the present model, a turning point of organic porosity occurs at the $\mathrm{Eq} R_{\mathrm{o}}$ value of about $3.0 \%$, corresponding to a burial depth of about $7500 \mathrm{~m}$ during geological history. The organic porosity begins to diminish with further increasing maturity or burial depth, and this decrease becomes drastic when the $\mathrm{Eq} R_{\mathrm{o}}$ value is over $3.5 \%$, resulting in a very low total porosity for shale with an $\mathrm{Eq} R_{\mathrm{o}}$ value $>4.0 \%$.

\subsection{Gas content of shale with a very high maturity}

The shale gas exploration and development carried out in the Lower Paleozoic shale of the Sichuan Basin over the past few years provide important data for estimating the gas content and yield of shale of a very high maturity (Table 2). The average gas content of the Lower Cambrian and Lower Silurian shales from the Weiyuan Block is 1.9 and $1.82 \mathrm{~m}^{3} / \mathrm{t}$, respectively (Huang et al. 2012a, b). For the Changning and Jiaoshiba blocks, the average gas content of the Lower Silurian shales is 1.93 and $2.96 \mathrm{~m}^{3} / \mathrm{t}$, respectively (Huang et al. 2012a; Guo and Zhang 2014). The gas content from the three blocks is similar to that of the Marcellus Shale and has a linear positive correlation with their TOC contents (Guo 2014; Wang et al. 2012a; Wang et al. 2013c). Wells with a high shale gas yield were reported from the three blocks. For example, the initial production of wells W204 in the Weiyuan Block, N201-H1 in the Changning Block, and JY1HF in the Jiaoshiba Block is $16.5 \times 10^{4} \mathrm{~m}^{3} / \mathrm{d}, 15 \times 10^{4} \mathrm{~m}^{3} / \mathrm{d}$, and $20.3 \times 10^{4} \mathrm{~m}^{3} / \mathrm{d}$, respectively (Hu et al. 2014; Wang 2014), and the gas yield has a positive correlation with the fluid pressure coefficient of these shale systems (Hu et al. 2014). A comparison of their $\mathrm{Eq} R_{\mathrm{O}}$ values between the three blocks indicates that the sequence of maturity from high to low is Jiaoshiba, 
Porosity, \%

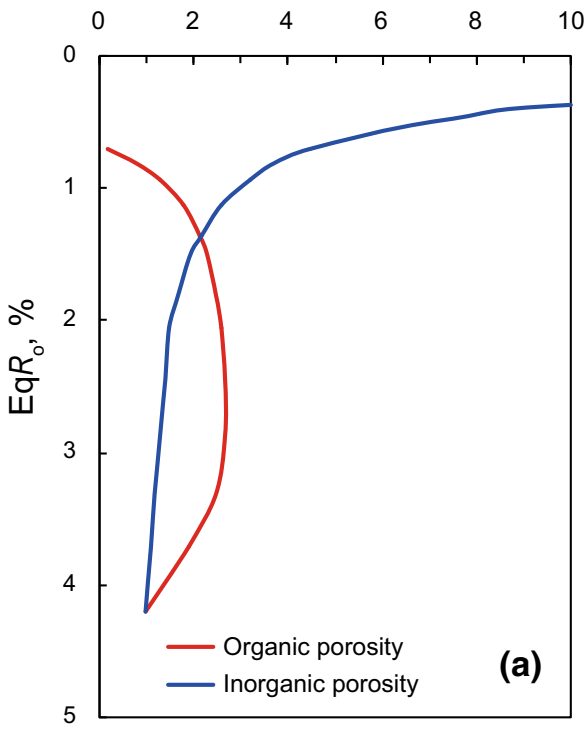

Porosity, \%

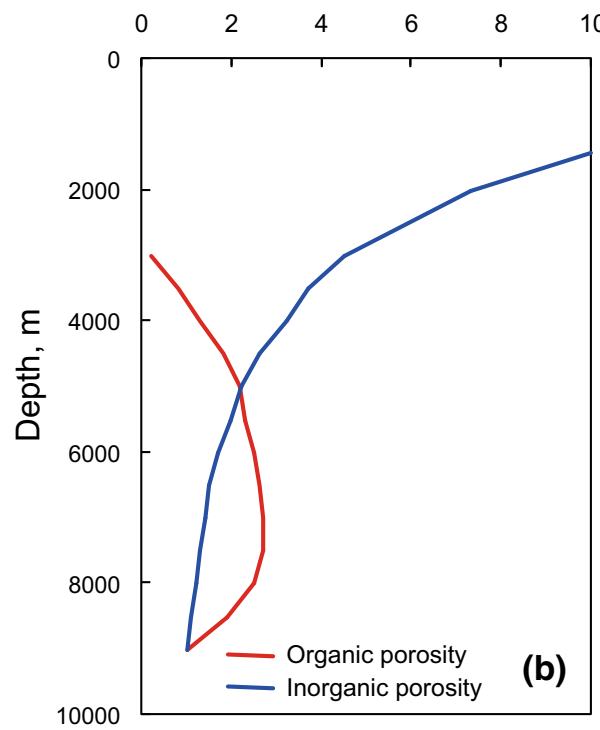

Fig. 5 Conceptual model of porosity evolution with maturity (a) and burial depth (b) for the Lower Paleozoic shale in south China

Table 2 Data of maturity and shale gas development of the Lower Paleozoic shale from the Sichuan Basin

\begin{tabular}{|c|c|c|c|c|}
\hline Shale & $\begin{array}{l}\text { Lower Silurian } \\
\text { shale in the } \\
\text { Weiyuan Block }\end{array}$ & $\begin{array}{l}\text { Lower Cambrian } \\
\text { shale in the } \\
\text { Weiyuan Block }\end{array}$ & $\begin{array}{l}\text { Lower Silurian } \\
\text { shale in the } \\
\text { Changning Block }\end{array}$ & $\begin{array}{l}\text { Lower Silurian } \\
\text { shale in the } \\
\text { Jiaoshiba Block }\end{array}$ \\
\hline $\mathrm{Eq} R_{\mathrm{o}}, \%$ & $\begin{array}{l}1.8(\mathrm{~W} 106)^{\mathrm{a}} \\
2.45(\mathrm{~W} 201)^{\mathrm{d}}\end{array}$ & $2.68-2.80^{\mathrm{c}} ; 2.85(\mathrm{~W} 117)^{\mathrm{d}}$ & $3.21^{\mathrm{e}}$ & $3.4^{\mathrm{d}}$ \\
\hline Total porosity, $\%$ & $(1.7-5.87) / 4.2^{\mathrm{a}}$ & $(0.82-4.86) / 2.44^{\mathrm{c}}$ & $\begin{array}{l}(2.4-7.2) / 5.5 \\
(\mathrm{CX} 1)^{\mathrm{f}}\end{array}$ & $(1.2-8.0) / 4.5^{\mathrm{h}}$ \\
\hline Gas content, $\mathrm{m}^{3} / \mathrm{t}$ & $(0.30-5.09) / 1.82^{\mathrm{a}}$ & $(0.27-6.02) / 1.9^{\mathrm{c}}$ & $(2.90-3.5) / 1.93^{\mathrm{a}}$ & $(0.44-5.19) / 2.96^{\mathrm{i}}$ \\
\hline Pressure coefficient of representative well & 1.96 (well W204) $^{\mathrm{b}}$ & $0.92(\mathrm{~W} 201)^{\mathrm{b}}$ & $2.03(\mathrm{~N} 201)^{\mathrm{g}}$ & $1.55(\mathrm{JY} 1 \mathrm{HF})^{\mathrm{g}}$ \\
\hline Initial production of representative well, $10^{4} \mathrm{~m}^{3} / \mathrm{d}$ & $16.5(\mathrm{~W} 204)^{\mathrm{b}}$ & $2.83(\mathrm{~W} 201 \mathrm{H} 3)^{\mathrm{c}}$ & $15(\mathrm{~N} 201-\mathrm{H} 1)^{\mathrm{g}}$ & $20.3(\mathrm{JY} 1 \mathrm{HF})^{\mathrm{j}}$ \\
\hline
\end{tabular}

${ }^{\mathrm{a}}$ Huang et al. (2012a); ${ }^{\mathrm{b}} \mathrm{Yu}(2014) ;{ }^{\mathrm{c}}$ Huang et al. (2012b); ${ }^{\mathrm{d}}$ Data from the present study; ${ }^{\mathrm{e}}$ Wang et al. (2009b); ${ }^{\mathrm{f}}$ Wang et al. (2012a, b); ${ }^{\mathrm{g}}$ Hu et al. (2014); ${ }^{\mathrm{h}} \mathrm{Li}$ et al. (2014); ${ }^{\mathrm{i}}$ Guo et al. (2014); ${ }^{\mathrm{j}}$ Wang (2014)

Changning, and Weiyuan. The $\mathrm{Eq} R_{\mathrm{O}}$ value of the Lower Silurian shales from the Jiaoshiba and Changning blocks is greater than $3.0 \%$, but their gas content and yield are still very high and are not affected by the maturity according to the available data (Table 2). The Marcellus Shale has two core gas areas: the southern west area and northern east area of the basin, with an $R_{\mathrm{o}}$ value of $1.5 \%-2.5 \%$ and $2.0 \%-3.5 \%$, respectively. The initial production from some representative wells exceeds $20 \times 10^{4} \mathrm{~m}^{3} / \mathrm{d}$ (Zagorski et al. 2011). These examples indicate that, within a definite range of maturity $\left(R_{\mathrm{O}}\right.$ or $\left.\mathrm{Eq} R_{\mathrm{O}}<3.5 \%\right)$, shale with a very high maturity still has a great shale gas potential.

Jarvie et al. (2007) proposed a positive correlation between maturity and gas production based on Barnett Shale data, but their model limited to an $R_{\mathrm{o}}$ value of up to about $2.5 \%$ and lacked data from higher maturity shales. Nie et al. (2011), based on data of 41 shale samples from the Lower Paleozoic strata in the Sichuan Basin and its surrounding areas, found that maturity does not have a significant effect on the gas content of shale even if the $\mathrm{Eq} R_{\mathrm{O}}$ value is as high as $3.0 \%$. In the present study, a conceptual model of shale gas content versus maturity is preliminarily suggested, which is based on the available data from the Lower Paleozoic shale of the Sichuan Basin as well as the North American shale (Fig. 6). According to this model, within a maturity range of $2 \%-3.5 \%$ of $R_{\mathrm{o}}$ or $\mathrm{Eq} R_{\mathrm{o}}$, shale gas content and yield and industrial shale gas potential would not be significantly reduced with increasing maturity, but exploration risk will increase greatly when the $R_{\mathrm{O}}$ or $\mathrm{Eq} R_{\mathrm{O}}$ value is over $3.5 \%$ due to the significant decrease of total porosity. Based on the maturity 


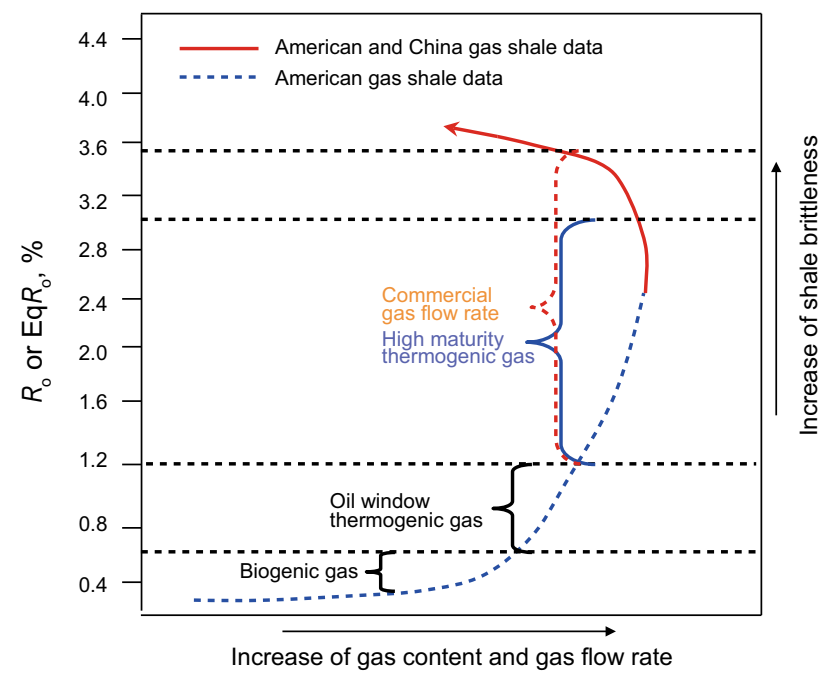

Fig. 6 A conceptual model of gas content versus maturity of shale (supplemented and modified after Jarvie et al. 2007)

distribution of the Lower Silurian and Lower Cambrian shales in south China, most of the Lower Silurian shale has an $\mathrm{Eq} R_{\mathrm{o}}$ value of $2.0 \%-3.0 \%$, with few area $>3.5 \%$ (Nie et al. 2009; Wang et al. 2009a; 2013b), and the Lower Cambrian shale is mainly between $2.5 \%$ and $3.5 \%$ in the Sichuan Basin (Zou et al. 2014), while the Cambrian shale with an $R_{\mathrm{o}}$ value $>3.5 \%-4.0 \%$ is basically located in the Lower Yangtze region (Nie et al. 2009), covering an area of less than $30 \%$ of the whole Cambrian shale.

Therefore, in spite of the very high maturity of the Lower Paleozoic shale in south China, gas content and yield are not significantly affected within a definite maturity range $\left(\mathrm{Eq} R_{\mathrm{o}}<3.5 \%\right)$, and maturity is not the main controlling factor for gas content and yield in this area.

\section{Tectonic deformation and gas content of shale}

The Lower Paleozoic strata in south China experienced a few significant tectonic deformations related to the Caledonian, Indo-China, Yanshan, and Himalayan movements (Wang et al. 2012a; Li et al. 2013a), but the late YanshanHimalayan tectonic movement has had the greatest effect on shale gas exploration and development of the Lower Paleozoic shale ( $\mathrm{Li}$ et al. 2013a). The tectonic deformation led to strong uplifting and denudation in the whole Yangtze region. Most of the area outside the Sichuan Basin underwent faulting and folding (Deng et al. 2009; Ma et al. 2006; Guo et al. 2014; Wang et al. 2013b; Wei et al. 2014). Similar to coal bed methane in China, the preservation of the Lower Paleozoic shale gas is mainly controlled by the intensity and pattern of the tectonic deformation (Guo and Zhang 2014; Guo 2014; Guo et al. 2014; Hu et al. 2014; Song et al. 2005, 2009). The tectonic deformation can be largely divided into two patterns. One is a simple uplifting, with or without folding (called an uplifting/folding pattern in the present paper), represented by the Sichuan Basin. Another is a combination of uplifting, folding, and faulting (called a faulting/folding pattern in the present paper), which may cover most of the Yangtze region outside the Sichuan Basin, represented by the shale gas blocks in southeast Chongqing. The present study will focus on the discussion of shale gas content and loss under the background of the two types of tectonic deformation.

\subsection{Uplifting/folding and loss of shale gas}

In the Sichuan Basin, the strong uplifting led to the erosion of the Lower Cretaceous-Jurassic strata after the late Cretaceous, with a total erosion thickness of 2000-5000 m (Hu et al. 2014; Wang and Xiao 2010; Zou et al. 2014), and, as a result, a portion of the Lower Paleozoic shale has a current burial depth suitable for shale gas exploitation ( $\mathrm{Li}$ et al. 2013a). In the southeastern area of the Sichuan Basin, the shale system with a strong overpressure is far away from faults, eroded surfaces, and basin edges, with a pressure coefficient generally greater than 1.5 and up to 2.25 (e.g., well Y101) (Hu et al. 2014), which implies that simple uplifting/folding can basically retain the fluid pressure coefficient of a shale system. In the process of uplifting and erosion, the fluid pressure will increase with decreasing temperature and pressure (Zhou et al. 2014b), which may break its original dynamic balance with a significant loss of shale gas.

In the present study, the Lower Silurian shale from the Fuling Block was taken as an example to establish a geological model of shale gas storage capacity and loss (Fig. 7). For this model, the absorbed gas content and adsorbed phase volume were calculated using high-pressure adsorption experimental data at different temperatures $\left(40-120^{\circ} \mathrm{C}\right.$ ) of a Lower Silurian shale (total porosity $=3.25 \%$ ) from the southern area of the Sichuan Basin, the free gas content was simulated by PVTsim software (Zhou et al. 2014b), and the related geological parameters include a constant pressure coefficient of 1.5 during uplifting (Hu et al. 2014), a gas saturation of $80 \%$ (Wei and Wei 2014), a geothermal gradient of $2.5^{\circ} \mathrm{C} / 100 \mathrm{~m}$, and a surface temperature of $15^{\circ} \mathrm{C}$. The maximum burial depth of the Lower Silurian shale in the Fuling Block was estimated to be about $7000 \mathrm{~m}$ ( $\mathrm{Li}$ et al. 2013a), with a total gas content of $3.79 \mathrm{~m}^{3} / \mathrm{t}$ for this shale sample (calculated by using its gas-filling porosity of $2.6 \%$ under the above conditions). During the uplifting, the loss of shale gas could be roughly divided into three stages. From 7000 to $4000 \mathrm{~m}$, the lost gas is less than $5 \%$. From 4000 to $2000 \mathrm{~m}$, the loss rate increases, with a cumulative amount of up to $20 \%$. With further uplifting, the gas loss is 

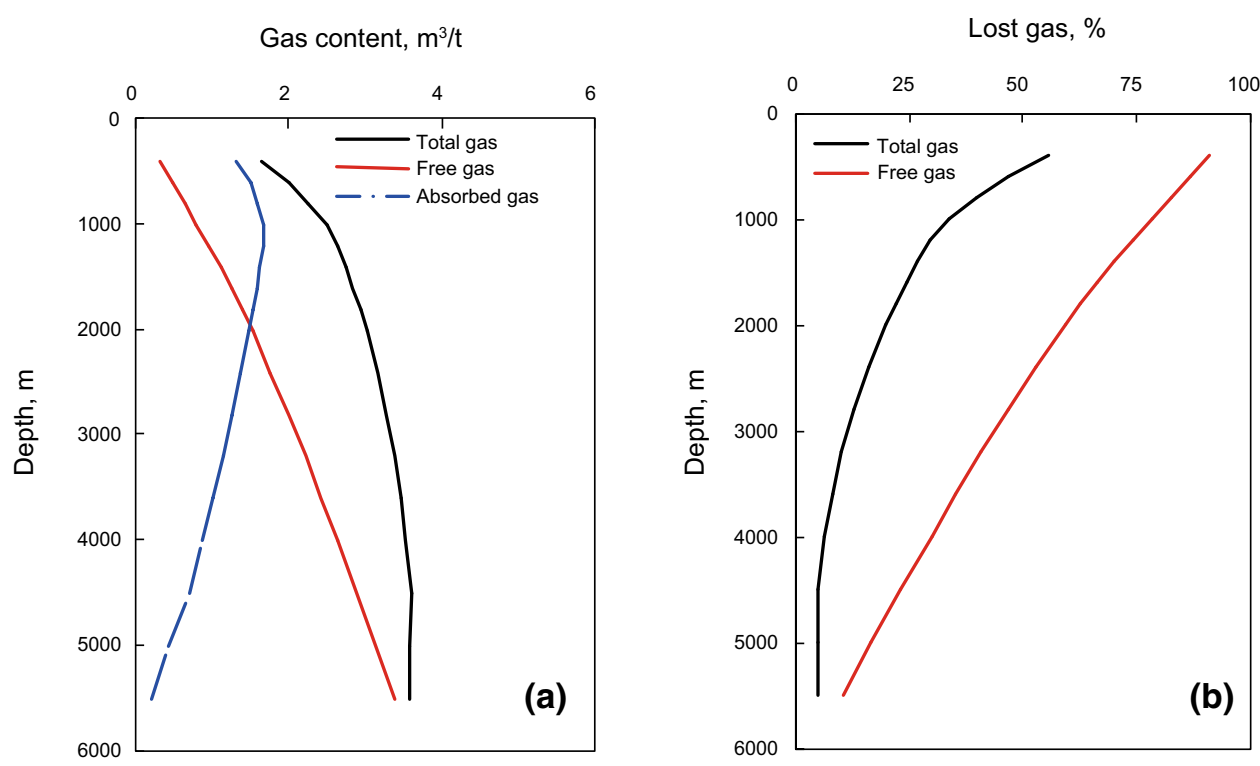

Fig. 7 A geological model of gas content (a) and loss (b) of the Lower Silurian shale in the Sichuan Basin (a geothermal gradient of $2.5{ }^{\circ} \mathrm{C} /$ $100 \mathrm{~m}$, a surface temperature of $15{ }^{\circ} \mathrm{C}$, a fluid pressure coefficient of 1.5 , and a gas-filling porosity of $2.6 \%$ )

massive, with a cumulative loss of over $33 \%$ as the depth decreases to $1000 \mathrm{~m}$. According to the changes in both free gas and absorbed gas contents during the uplifting, it is obvious that a portion of the reduced free gas is transformed into absorbed gas, and the remaining portion is lost. When the burial depth is greater than $5000 \mathrm{~m}$, the total gas is basically composed of free gas. When uplift reduces the burial depth to 4000,2000 , and $1000 \mathrm{~m}$, the percentage of free gas becomes $75 \%, 50 \%$, and $32 \%$, respectively. Therefore, the lost gas is mainly free gas during the uplifting, and a sufficient current burial depth $(>2000-2500 \mathrm{~m})$ is a key condition to obtain a high shale gas yield.

It should be pointed out that the illustration of Fig. 7 is only an example. It is limited by the geochemical and reservoir properties of the studied sample as well as the specific geological conditions. The geological model of shale gas content and loss would vary with different types of shale and their geological conditions, but the basic characteristics presented in Fig. 7 should be representative of the Lower Paleozoic shale in south China.

\subsection{Faulting/folding and loss of shale gas}

For the current exploration blocks outside the Sichuan Basin, the shale system of the Lower Paleozoic strata has a normal or negative pressure, with a pressure coefficient of $0.8-1.2$ (Hu et al. 2014). Thus, the calculation of the lost gas in these areas should include two aspects: (1) gas loss related to the decrease of temperature and pressure caused by the uplifting as indicated above, and (2) gas loss related to the reduction of fluid pressure coefficient caused by the faulting and folding.

Taking the Lower Silurian shale in the southeast area of Chongqing as an example, it was assumed that the paleopressure coefficient of the shale system was 1.5 before the uplifting and the current pressure coefficient is 1.0 (Guo 2014). This decrease of the pressure coefficient is assumed to be attributed to the faulting and folding. In order to make a comparison with the gas model of the uplifting/folding (Fig. 7), a total porosity of $3.25 \%$ and a gas saturation of $80 \%$ (no available data in this area at present) were applied.

With the constraint of the above parameters, the highpressure adsorption experimental data and free gas calculation method as described in the above section (Sect. 4.1) were applied to calculate the gas content at different burial depths for the faulting/folding block. Combined with the lost gas caused by the decrease of pressure coefficient in the shale system, the geological model of shale gas content and loss was established (Fig. 8).

Based on the maximum burial depth of $7000 \mathrm{~m}$ of the Lower Silurian shale in the southeast area of Chongqing during geological history, the total gas content was calculated to be $3.79 \mathrm{~m}^{3} / \mathrm{t}$ before the uplifting. The current burial depth ranges mainly from 5000 to $500 \mathrm{~m}$. At a depth of 5000-4000 m, the total gas content only slightly decreases and the reduced free gas is basically turned into absorbed gas. At a depth of 4000-2000 m, the total gas content decreases, most of the reduced free gas becomes absorbed gas, and the absorbed gas content exceeds the free gas content at a depth of about $2500 \mathrm{~m}$. At a shallower depth 

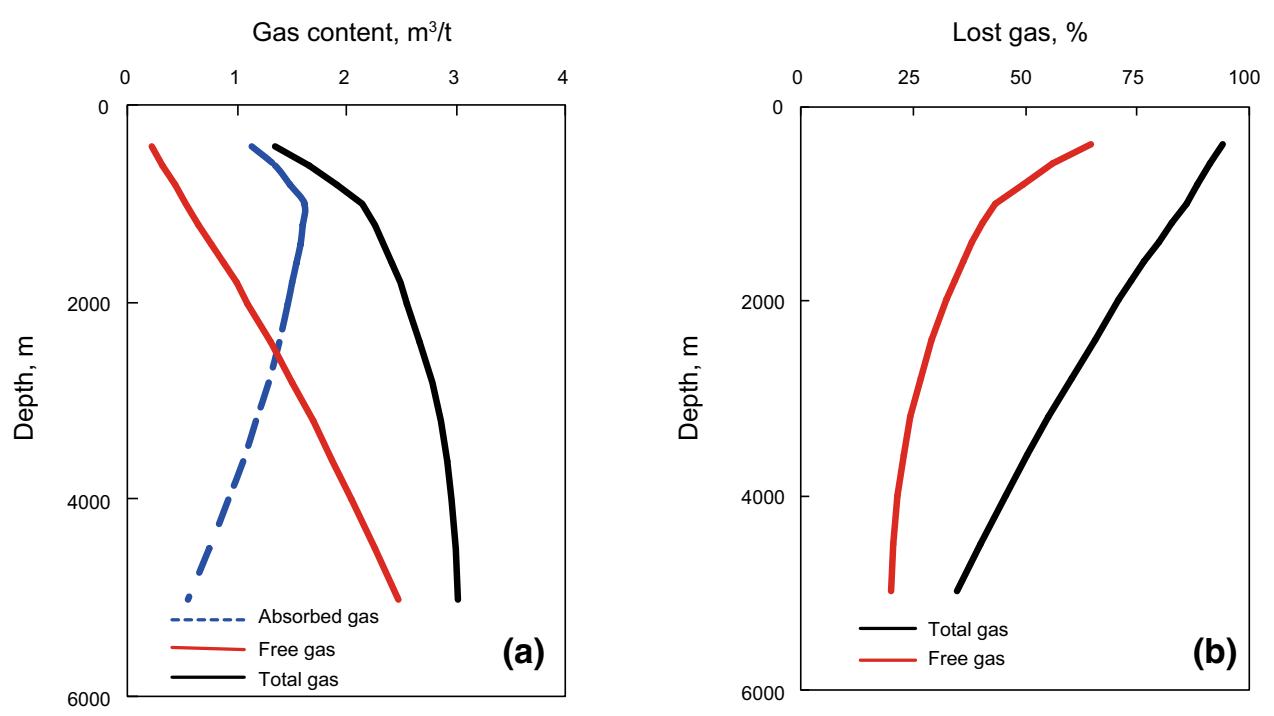

Fig. 8 A geological model of gas content (a) and loss (b) of the Lower Silurian shale in the southeast area of Chongqing (a geothermal gradient of $2.5{ }^{\circ} \mathrm{C} / 100 \mathrm{~m}$, a surface temperature of $15{ }^{\circ} \mathrm{C}$, a decrease of fluid pressure coefficient from 1.5 to 1.0 , a TOC content of $2.53 \%$, and a gasfilling porosity of $2.6 \%$ )

$(<2000 \mathrm{~m})$, a large amount of gas is lost and the shale gas is dominated by the absorbed gas. Thus, the decrease of the fluid pressure coefficient in the shale system is accompanied by a great deal of free gas loss. At a depth of 4000 , 3000,2000 , and $1000 \mathrm{~m}$, the lost free gas amounts to $46 \%$, $58 \%, 71 \%$, and $86 \%$, respectively.

By comparison between the two models (Figs. 7, 8), it can be seen that, for the same burial depth, the fluid pressure coefficient has no significant effect on the absorbed gas, but has a great influence on the free gas. For a shale system with a lower pressure coefficient, the free gas content is much less and the ratio of the free gas to absorbed gas is also obviously lower (Fig. 9). Therefore, free gas is controlled by the fluid pressure coefficient of the shale system. In a faulted-folded zone with a lower fluid pressure coefficient, the lost gas is basically free gas, which leads to a lower yield of shale gas. Deep burial shale with a relatively higher fluid pressure/a larger porosity, as a result of a higher content of free gas, would be a basic condition to achieve a high shale gas yield in the folded-faulted zone.

\section{Main controlling factors and enrichment area of shale gas}

\subsection{Main controlling factors of shale gas}

Although a series of factors can affect shale gas production (Jarvie et al. 2007) and those factors may vary significantly for different basins or regions, a high content of gas-inplace (GIP) and effective fracturing properties of shale are

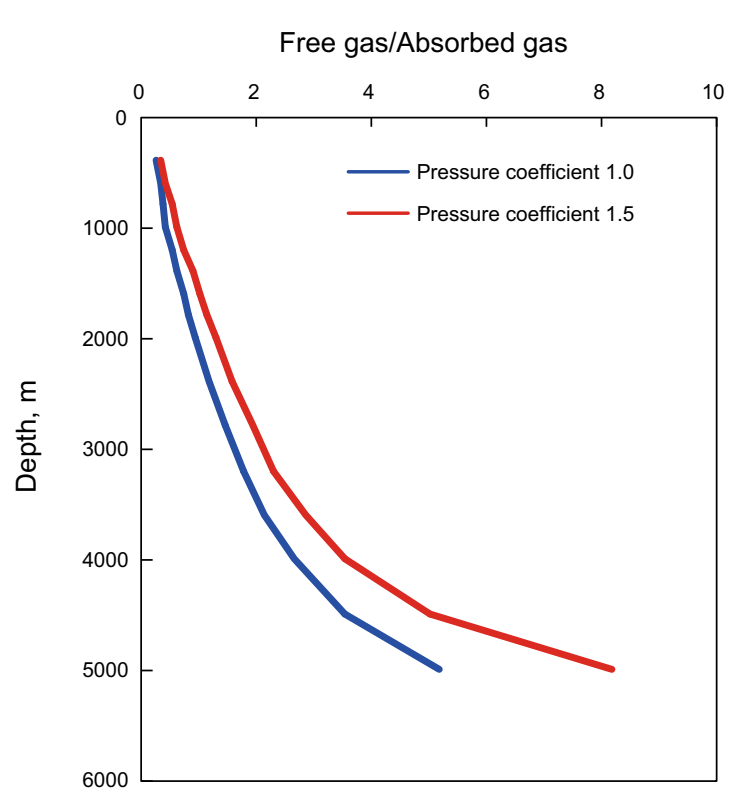

Fig. 9 Changes in the ratio of free gas to absorbed gas with burial depth for two shale systems with different pressure coefficients

mostly of importance. For a specific basin or block, there is a main controlling factor for shale gas production. For examples, maturity is the main controlling factor for the Barnett Shale and the high-yield wells are mostly located in areas with a higher maturity $\left(R_{\mathrm{O}}>1.1 \%-1.2 \%\right)$ (Jarvie et al. 2007); the Marcellus Shale has two core areas and they have a very high TOC content (with an average of $4 \%-10 \%$ ) although their maturity is quite different (Zagorski et al. 2011); the gas production of the Haynesville Shale is obviously restricted by its mineral 
compositions, and two core areas have a strong overpressure, located in quartz- and carbonate-rich zones, respectively (Buller and Dix, 2009; Hammes et al. 2010). The maturity of the lower Paleozoic shale in south China is very high, but the most is still within the maturity range $\left(2.0 \%<\mathrm{Eq} R_{\mathrm{o}}<3.5 \%\right)$ with an industrial potential, and the preservation condition related to the tectonic deformation is the main factor to control gas content in this kind of area. Shale with a super high maturity $\left(\mathrm{Eq} R_{\mathrm{o}}>3.5 \%\right)$ is believed to be a high risk for industrial shale gas potential.

\subsection{Prediction of enrichment area of shale gas}

Referring to relevant literatures (Boyer et al. 2006; Burnaman et al. 2009; Curtis et al. 2009; Hill and Nelson 2000; Jarvie et al. 2007; Wang et al. 2012a, 2013c; Li et al. $2013 b$ ), the present study proposes a few parameters for predicting a shale gas enrichment area in the lower Paleozoic strata in south China (Table 3). As indicated in the front sections of the present paper, some basic geological and geochemical parameters of the lower Paleozoic shale in south China can be compared with those of the gas shale in North America, mainly including TOC content, brittle mineral content, clay mineral content, and effective shale thickness. These parameters can use the empirical data from the North America shale as presented by some Chinese authors (Wang et al. 2012a; Li et al. 2013b). Focusing on two characteristics (very high maturity and strong tectonic deformation) of the lower Paleozoic shale in south China, the present study modified the limiting value of the maturity and added the burial depth and pressure coefficient as evaluation parameters.

The lower limit of maturity for the North American shale with an industrial gas potential is usually considered to be an $R_{\mathrm{o}}$ value $>1.2 \%$ (Curtis et al. 2009; Jarvie et al. 2007), and the upper limit of maturity is not taken into account mainly because the maturity of the North

Table 3 Predictive parameters of enrichment area of shale gas for the lower Paleozoic shale in south China

\begin{tabular}{|c|c|c|}
\hline \multirow[t]{2}{*}{ Parameters } & \multicolumn{2}{|l|}{ Enrichment area } \\
\hline & $\begin{array}{l}\text { Uplifted/folded } \\
\text { area (Sichuan } \\
\text { Basin) }\end{array}$ & $\begin{array}{l}\text { Folded-faulted } \\
\text { area (outside the } \\
\text { Sichuan Basin) }\end{array}$ \\
\hline TOC, \% & $>2.0$ & $>3.0$ \\
\hline $\mathrm{Eq} R_{\mathrm{o}}, \%$ & $<3.5$ & $<3.5$ \\
\hline Total porosity, \% & $>4.0$ & $>4.0$ \\
\hline Brittle mineral, \% & $>40$ & $>40$ \\
\hline Thickness, m & $>30$ & $>30$ \\
\hline Burial depth, m & $>1500$ & $>3000$ \\
\hline Fluid pressure coefficient & $>1.2$ & $>1.0$ \\
\hline
\end{tabular}

American gas shale is usually lower, not exceeding the gas generation limit (Curtis 2002). As previously mentioned, the maturity of the lower Paleozoic shale in south China is very high, with some areas where the shale maturity is over the gas generation limit (Cheng and Xiao 2013). High gas production from shale with an $R_{\mathrm{O}}$ or $\mathrm{Eq} R_{\mathrm{O}}$ value of up to $3.0 \%-3.5 \%$ has been reported during recent few years (Zagorski et al. 2011; Guo et al. 2014), which has broken through the upper limit value of $3.0 \%$ of $R_{\mathrm{o}}$ suggested by Burnaman et al. (2009) for a commercial shale gas reservoir. However, as shale maturity is significantly over its gas generation limit, a further burial may cause an obvious decrease of the porosity, which will reduce gas content and increase risk. When shale has matured to exceed the hydrocarbon gas preservation threshold (i.e., $R_{\mathrm{O}}>4 \%-$ $5 \%$ ), there is no longer shale gas potential (Burnaman et al. 2009; Li et al. 2013a). Therefore, the $\mathrm{Eq} R_{\mathrm{o}}$ value of $3.5 \%$ is proposed as the upper limit of the shale gas enrichment area.

Gas shale with commercial production in North America has a burial depth mainly in the range of 1500-3500 m, and the burial depth for economically recoverable shale gas is generally limited to $4000-5000 \mathrm{~m}$ (EIA 2013), which is mainly based on the consideration of the technology and cost related to shale gas exploitation. In fact, shale with a deeper burial has a greater gas content and free gas proportion than shale with a shallower burial (Figs. 7, 8). The evaluation parameters for the North America shale do not include the shallower limit of the burial depth, and successful commercial exploitation has been achieved in some shallow shales $(<1000 \mathrm{~m})$ (Curtis 2002), which is mainly attributed to their greater porosity with a high free gas content (Curtis 2002; Li et al. 2013b). Porosity of the Lower Paleozoic shale in south China is significantly lower than that of the North American shale (Wang et al. 2013a). To ensure a certain amount of gas storage capacity, especially free gas reserves, the Lower Paleozoic shale in south China needs a higher fluid pressure coefficient and/or a greater depth. Taking a gas content of $2.80 \mathrm{~m}^{3} / \mathrm{t}$ as the lower limit of shale with a commercial shale gas potential suggested by Halliburton (Wang et al. 2012a), shale with a gas-filling porosity of $2.6 \%$ should have a burial depth of about $1500 \mathrm{~m}$ to achieve this gas content under a pressure coefficient of 1.5 according to Fig. 7. When the pressure coefficient is 1.0 , the corresponding depth is about $3000 \mathrm{~m}$ according to Fig. 8. Actually, except for the lower Silurian shale in the Sichuan Basin, the average gas-filling porosity of the other lower Paleozoic shales in the Upper Yangtze area rarely exceeds $2.6 \%$ from the available data (Huang et al. 2012b; Huang and Shen 2015; Yi and Zhao 2014; Yu et al. 2014), which means that shale should have a greater burial depth to meet this gas content. Therefore, burial depth has an important significance for the Lower 
Paleozoic shale gas exploration and development in south China. Within a definite maturity range $(2.0 \%<$ $\mathrm{Eq} R_{\mathrm{o}}<3.5 \%$ ), the gas-in-place and free gas content increases with increasing burial depth. To exploit shale gas with a greater depth will become a trend. For example, the core shale gas area in north Canada has reached $5000 \mathrm{~m}$ (Ross and Bustin 2007; 2008). The present paper does not set the deeper limit of burial, but suggests a shallower burial limit of 1500 and $3000 \mathrm{~m}$ for the uplifted/folded and faulted/folded areas, respectively.

The evaluation of the North American shale does not include the pressure coefficient of a shale system as a parameter, which is also because of a greater porosity of the shale. Commercial shale gas production has been achieved in shale systems with a normal pressure, but an overpressure can still greatly increase the initial production, thus improving the commercial value (Curtis 2002; Curtis et al. 2008; Jarvie et al. 2007).

There exists a good positive correlation between the initial production of shale gas and the fluid pressure coefficient for the Lower Paleozoic shale in south China $(\mathrm{Hu}$ et al. 2014), and the high-yield wells in the Sichuan Basin are almost always associated with an overpressure. Wells outside the Sichuan Basin with an industrial shale gas production are reported at a normal pressure, such as well PY-1 with a yield of $2.5 \times 10^{4} \mathrm{~m}^{3} / \mathrm{d}$ (a pressure coefficient of 0.90-1.0), but for a negative pressure shale system, there is no report of an industrial capacity, for example, well Z101 without any yield (a pressure coefficient of 0.80) (Guo 2014; Guo et al. 2014). To search for a block with better preservation conditions and a higher gas content from the faulted/folded area will be a real challenge for the exploration and development of the lower Paleozoic shale gas in south China. The pressure coefficient is an important parameter of shale gas preservation conditions, with a dominant control on shale gas content and production for the lower Paleozoic shale in south China. Pressure coefficients of 1.2 and 1.0 are suggested as the lower limit for shale gas enrichment in the uplifted/folded and faulted/folded areas, respectively.

It should be particularly pointed out that shale gas exploration and development in China has only just started. There are only about 300-400 wells drilled specifically for shale gas. Among them, the number of development wells is less than 150. The targeted formation is mainly the lower Silurian shale, and few data are available for the lower Cambrian shale. Therefore, the proposed criteria are primarily intended for the evaluation of the lower Silurian shale, but whether it is suitable for the lower Cambrian shale requires the input of more data from further exploration and development.

\section{Conclusions}

Through a comprehensive investigation of the geochemical characteristics, reservoir properties, and gas content of the Lower Paleozoic marine shale from the Sichuan Basin and its surrounding areas in south China, we have arrived at the following conclusions:

(1) The shale has a very high maturity, with an $\mathrm{Eq} R_{\mathrm{o}}$ value of $1.9 \%-6.2 \%$. Within the main maturity range $\left(2.5 \%<\mathrm{Eq} R_{\mathrm{o}}<3.5 \%\right)$, the porosity develops well, mainly between $3 \%$ and $5 \%$, and has a positive relationship with TOC content. Shale with a super high maturity $\left(\mathrm{Eq} R_{\mathrm{o}}>3.5 \%\right)$ has a quite low porosity and has a low potential for industrial shale gas.

(2) Shale gas content and yield are mainly constrained by the preservation conditions when the maturity is less than $3.5 \% \mathrm{Eq} R_{\mathrm{o}}$. In the Sichuan Basin where the tectonic deformation is relatively gentle, the shale system is generally overpressure. The strong uplifting and erosion has not led to a big loss of shale gas (a burial depth $>2000 \mathrm{~m}$ ), still with an industrial potential. In the faulted/folded zone outside the Sichuan Basin (a burial depth $<2000-3000 \mathrm{~m}$ ), folding and faulting may lead to a big loss of shale gas, thus decreasing the production capacity.

(3) Burial depth, pressure coefficient, and maturity upper limit $\left(\mathrm{Eq} R_{\mathrm{o}}<3.5 \%\right)$ were suggested to be used as the evaluation parameters of shale gas enrichment areas. It was predicted that gentle synclines or anticlines where the shale has a burial depth $>3000 \mathrm{~m}$ are the favorable areas for shale gas in the faulted-folded area outside the Sichuan Basin in south China, and these will become the focus for future exploration and development.

Acknowledgments This study was jointly supported by the National Key Basic Research Program of China (973 Program: 2012CB214700), the Strategic Priority Research Program of the Chinese Academy of Sciences (XDB10040300), and the National Natural Science Foundation of China (41321002).

Open Access This article is distributed under the terms of the Creative Commons Attribution 4.0 International License (http://crea tivecommons.org/licenses/by/4.0/), which permits unrestricted use, distribution, and reproduction in any medium, provided you give 
appropriate credit to the original author(s) and the source, provide a link to the Creative Commons license, and indicate if changes were made.

\section{References}

Boyer C, Kieschnick J, Suarez-Rivera R, et al. Producing gas from its source. Oilfield Rev. 2006;18:36-49.

Burnaman M, Xia WW, Shelton J. Shale gas play screening and evaluation criteria. China Pet Explor. 2009;14:51-64.

Buller D, Dix MC. Petrophysical evaluation of the Haynesville shale in northwest Louisiana and northeast Texas. Gulf Coast Assoc Geol Soc Trans. 2009;59:127-43.

Cander H. Sweet spots in shale gas and liquids plays: prediction of fluid composition and reservoir pressure. AAPG Annual Convention and Exhibition, Long Beach, California, April 22-25, 2012.

Chalmers GR, Bustin RM. Lower Cretaceous gas shales in northeastern British Columbia, Part I: geological controls on methane sorption capacity. Bull Can Pet Geol. 2008;56(1):1-21.

Chalmers GR, Bustin RM, Power IM. Characterization of gas shale pore systems by porosimetry, pycnometry, surface area, and field emission scanning electron microscopy/transmission electron microscopy image analyses: examples from the Barnett, Woodford, Haynesville, Marcellus, and Doig units. AAPG Bull. 2012;96(6):1099-119.

Chen J, Xiao XM. Evolution of nanoporosity in organic-rich shales during thermal maturation. Fuel. 2014;129:173-81.

Cheng P, Xiao XM. Gas content of organic-rich shales with very high maturities. J China Coal Soc. 2013;8(5):737-41 (in Chinese).

Curtis JB, Hill DG, Lillis PG. US Shale gas resources: classic and emerging plays, the resource pyramid and a perspective on future E\&P. Prepared for presentation at AAPG Annual Convention. San Antonio, Texas. April 20-23, 2008.

Curtis JB, Jarvie DM, Ferworn KA. Applied geology and geochemistry of gas shales. AAPG Conference 2009, Denver Colorado, 2009.

Curtis JB. Fractured shale-gas systems. AAPG Bull. 2002;86: 1921-38.

Curtis ME, Ambrose RJ, Sondergeld CH, et al. Structural characterization of gas shales on the micro- and nano-scales. Canadian Unconventional Resources and International Petroleum Conference, 19-21 October, Calgary, Alberta, Canada. Society of Petroleum Engineers (SPE 137693), pp. 1-15, 2010.

Curtis ME, Cardott BJ, Sondergeld CH, et al. Development of organic porosity in the Woodford Shale with increasing thermal maturity. Int J Coal Geol. 2012;103:26-31.

Deng B, Liu SG, Liu S, et al. Restoration of exhumation thickness and its significance in Sichuan Basin, China. J Chengdu Univ Technol (Sci Technol Edn). 2009;36(6):675-86 (in Chinese).

Fishman NS, Hackley PC, Lowers HA, et al. The nature of porosity in organic-rich mudstones of the Upper Jurassic Kimmeridge Clay Formation, North Sea, offshore United Kingdom. Int J Coal Geol. 2012;103:32-50.

Guo XS. Rules of two-factor enrichment for marine shale gas in southern China-Understanding from the Longmaxi Formation shale gas in Sichuan Basin and its surrounding area. Acta Geol Sin. 2014;88(7):1209-18 (in Chinese).

Guo XS, Hu DF, Li YP, et al. Geological features and reservoiring mode of shale gas reservoirs in Longmaxi Formation of the Jiaoshiba Area. Acta Geol Sin. 2014;88(6):1811-21.

Guo TL, Liu RB. Implications from marine shale gas exploration breakthrough in complicated structural area at high thermal stage: taking Longmaxi Formation in well JY1 as an example. Nat Gas Geosci. 2013;24(4):643-51 (in Chinese).

Guo TL, Zhang HR. Formation and enrichment mode of Jiaoshiba shale gas field, Sichuan Basin. Pet Explor Dev. 2014;41(1): 28-36 (in Chinese).

Hill DG, Nelson CR. Gas productive fractured shales-an overview and update. Gas Tips. 2000;6(2):4-13.

$\mathrm{Hu}$ DF, Zhang HR, Ni K, et al. Main controlling factors for gas preservation conditions of marine shales in southeastern margins of the Sichuan Basin. Nat Gas Ind. 2014;34(6):17-23 (in Chinese).

Huang JL, Zou CN, Li JZ, et al. Shale gas accumulation conditions and favorable zones of Silurian Longmaxi Formation in south Sichuan Basin, China. J China Coal Soc. 2012a;37(5):782-7 (in Chinese).

Huang JL, Zou CN, Li JZ, et al. Shale gas generation and potential of the Lower Cambrian Qiongzhusi Formation in southern Sichuan Basin, China. Pet Explor Dev. 2012b;39(1):69-75 (in Chinese).

Huang L, Shen W. Characteristics and controlling factors of the formation of pores of a shale gas reservoir: a case study from Longmaxi Formation of the Upper Yangtze region, China. Earth Sci Front. 2015;22(1):374-85 (in Chinese).

Hammes U, Hamlin S, Eastwood R. Facies characteristics, depositional environments, and petrophysical characteristics of the Haynesville and Bossier shale-gas plays of east Texas and northwest Louisiana. Houston Geol Soc Bull. 2010;52(9):59-63.

Jarvie DM, Hill RJ, Ruble TE, et al. Unconventional shale-gas systems: the Mississippian Barnett Shale of north central Texas as one model for thermogenic shale gas assessment. AAPG Bull. 2007;91(4):475-99.

Li LJ, Yang F, Sun CM, et al. Tectonic movement and lower Silurian shale gas exploration potential in the southeast of Chongqing and west of Hunan and Hubei areas. J Oil Gas Technol. 2013a;35(4):68-71 (in Chinese).

Li XT, Shi WR, Guo MY, et al. Characteristics of marine shale gas reservoirs in the Jiaoshiba area of Fuling shale gas field. J Oil Gas Technol. 2014;36(11):11-5 (in Chinese).

Li YJ, Liu H, Zhang LH, et al. Lower limits of evaluation parameters for the lower Paleozoic Longmaxi shale gas in southern Sichuan Province. Sci China Earth Sci. 2013b;56(5):710-7.

Li YF, Fan TL, Gao ZQ, et al. Sequence stratigraphy of Silurian black shale and its distribution in the southeast area of Chongqing. Nat Gas Geosci. 2012;23(2):299-306 (in Chinese).

Liang DG, Guo TL, Chen JP, et al. Some progresses on studies of hydrocarbon generation and accumulation in marine sedimentary regions, southern China (Part 2): geochemical characteristics of four suits of regional marine source rocks, south China. Mar Origin Pet Geol. 2009;14(1):1-15 (in Chinese).

Liang DG, Guo TL, Chen JP, et al. Some progresses on studies of hydrocarbon generation and accumulation in marine sedimentary regions, southern China (Part 1): distribution of four suits of regional marine source rocks. Mar Origin Pet Geol. 2008;13(2):1-16 (in Chinese).

Loucks RG, Reed RM, Ruppel SC, et al. Morphology, genesis, and distribution of nanometer-scale pores in siliceous mudstones of the Mississippian Barnett Shale. J Sediment Res. 2009;79(12): 848-61.

Ma YS, Lou ZH, Guo TL, et al. An exploration on a technological system of petroleum preservation evaluation for marine strata in south China. Acta Geol Sin. 2006;80(3):406-17 (in Chinese).

Ma C, Ning N, Wang HY, et al. Exploration prospect of the Lower Cambrian Niutitang Formation shale gas in the west of Hunan and the east of Guizhou area. Spec Oil Gas Reserv. 2014;21(1):38-41 (in Chinese).

Mastalerz M, Schimmelmann A, Drobniak A, et al. Porosity of Devonian and Mississippian New Albany Shale across a 
maturation gradient: insights from organic petrology, gas adsorption, and mercury intrusion. AAPG Bull. 2013;97: 1621-43.

Mei LF, Liu ZQ, Tang JG, et al. Mesozoic intra-continental progressive deformation in western Hunan-Hubei-eastern Sichuan provinces of China: evidence from apatite fission track and balanced cross-section. Earth Sci. 2010;35(2):161-74 (in Chinese).

Milliken KL, Esch WL, Reed RM, et al. Grain assemblages and strong diagenetic overprinting in siliceous mudrocks, Barnett Shale (Mississippian), Fort Worth Basin, Texas. AAPG Bull. 2012;96(9):1553-78.

Milliken KL, Rudnicki M, Awwiller DN, et al. Organic matter-hosted pore system, Marcellus Formation (Devonian), Pennsylvania. AAPG Bull. 2013;97(2):177-200.

Modica CJ, Lapierre SG. Estimation of kerogen porosity in source rocks as a function of thermal transformation: example from the Mowry Shale in the Powder River Basin of Wyoming. AAPG Bull. 2012;96(1):87-108.

Nie HK, Tang X, Bian RK. Controlling factors for shale gas accumulation and prediction of potential development area in shale gas reservoir of south China. Acta Pet Sin. 2009;30(4):484-91 (in Chinese).

Nie HK, He FQ, Bao SJ. Peculiar geological characteristics of shale gas in China and its exploration countermeasures. Nat Gas Ind. 2011;31(11):111-6 (in Chinese).

Pan L, Xiao XM, Tian H, et al. A preliminary study on the characterization and controlling factors of porosity and pore structure of the Permian shales in Lower Yangtze region, Eastern China. Int J Coal Geol. 2015;146:68-78.

Ross DJK, Bustin RM. Shale gas potential of the Lower Jurassic Gordondale Member, northeastern British Columbia, Canada. Bull Can Pet Geol. 2007;55(1):51-75.

Ross DJK, Bustin RM. Characterizing the shale gas resource potential of Devonian Mississippian strata in the Western Canada sedimentary basin: application of an integrated formation evaluation. AAPG Bull. 2008;92:87-125.

Ross DJK, Bustin RM. The importance of shale composition and pore structure upon gas storage potential of shale gas reservoirs. Mar Pet Geol. 2009;26(6):916-27.

Song Y, Zhao MJ, Liu SB, et al. The influence of tectonic evolution on the accumulation and enrichment of coalbed methane (CBM). Chin Sci Bull. 2005;50(supp.):1-6.

Song Y, Liu SB, Zhao MJ, et al. Coalbed gas reservoirs: boundary types, main controlling factors of gas pooling, and forecast of gas-rich areas. Nat Gas Ind. 2009;29(10):4-9 (in Chinese).

Tang LJ, Cui M. Key tectonic changes, deformation styles and hydrocarbon preservation in middle-upper Yangtze region. Pet Geol Exp. 2011;33(1):12-6 (in Chinese).

Tian H, Pan L, Xiao XM, et al. A preliminary study on the pore characterization of Lower Silurian black shales in the Chuandong Thrust Fold Belt, southwestern China using low pressure $\mathrm{N}_{2}$ adsorption and FE-SEM methods. Mar Pet Geol. 2013;48:8-19.

Tian H, Pan L, Zhang TW, et al. Pore characterization of organic-rich Lower Cambrian shales in Qiannan Depression of Guizhou Province, Southwestern China. Mar Pet Geol. 2015;62:28-43.

$\mathrm{Tu}$ Y, Zou HY, Meng HP, et al. Evaluation criteria and classification of shale gas reservoirs. Oil Gas Geol. 2014;35(1):153-8 (in Chinese)

U. S. Energy Information Administration (EIA). World shale gas resources: An initial assessment of 14 regions outside the United States [EB/OL]. 2011-04-05. http://www.eia.gov.

U. S. Energy Information Administration (EIA). Technically recoverable shale oil and shale gas resources: An assessment of 137 shale formations in 41 countries outside the United States [EB/ OL]. 2013-06-13. http://www.eia.gov.

Valenza JJ, Drenzek N, Marques F, et al. Geochemical controls on shale microstructure. Geology. 2013;41(5):611-4.

Wang FY, Guan J, Feng WP, et al. Evolution of overmature marine shale porosity and implication to the free gas volume. Pet Explor Dev. 2013a;40(6):819-24.

Wang HY, Liu YZ, Dong DZ, et al. Scientific issues on effective development of marine shale gas in southern China. Pet Explor Dev. 2013b;40(5):574-9.

Wang YF, Xiao XM. An investigation of paleogeothermal gradients in the northeastern area of the Sichuan Basin. Mar Orig Petrol Geol. 2010;15(4):57-61 (in Chinese).

Wang YM, Dong DZ, Li JZ, et al. Reservoir characteristics of shale gas in Longmaxi Formation of the Lower Silurian, southern Sichuan. Acta Pet Sin. 2012a;33(4):551-61 (in Chinese).

Wang LS, Zou CY, Zheng P, et al. Geochemical evidence of shale gas existed in the Lower Paleozoic Sichuan Basin. Nat Gas Ind. 2009a;29(5):59-62 (in Chinese).

Wang SJ, Yang T, Zhang GS, et al. Shale gas enrichment factors and the selection and evaluation of the core area. Chin Eng Sci. 2012b;14(6):94-100 (in Chinese).

Wang SQ, Wang SY, Man L, et al. Appraisal method and key parameters for screening shale gas play. J Chengdu Univ Technol (Sci Technol Edn). 2013c;40(6):609-20 (in Chinese).

Wang SQ. Shale gas exploration and appraisal in China: problems and discussion. Nat Gas Ind. 2013;33(2):13-29 (in Chinese).

Wang SQ, Chen GS, Dong DZ, et al. Accumulation conditions and exploration prospects of shale gas in the Lower Paleozoic Sichuan Basin. Nat Gas Ind. 2009b;29(5):51-8 (in Chinese).

Wang ZG. Practice and cognition of shale gas horizontal well fracturing stimulation in Jiaoshiba of Fuling area. Oil Gas Geol. 2014;35(3):425-30 (in Chinese).

Wei $\mathrm{XH}$, Wang T, Li C, et al. Exploration prospect of shale gas in complex geological areas, southeastern Chongqing. Nat Gas Technol Econ. 2014;8(1):24-32 (in Chinese).

Wei ZH, Wei XF. Comparison of gas-bearing property between different pore types of shale: a case from the Upper Ordovician Wufeng and Longmaxi formations in the Jiaoshiba area, Sichuan Basin. Nat Gas Ind. 2014;34(6):37-41 (in Chinese).

Xiao XM, Song ZG, Zhu YM, et al. Summary of shale gas research in North American and revelations to shale gas exploration of Lower Paleozoic strata in China south area. J China Coal Soc. 2013;38(5):721-7 (in Chinese).

Yan DP, Wang XW, Liu YY. Analysis of fold style and its formation mechanism in the area of boundary among Sichuan, Hubei and Hunan. Geoscience. 2000;14(1):37-43 (in Chinese).

Yi TS, Zhao X. Characteristics and distribution patterns of the Lower Cambrian Niutitang shale reservoirs in Guizhou, China. Nat Gas Ind. 2014;34(8):8-14 (in Chinese).

Yu C, Nie HK, Zeng CL, et al. Shale reservoir space characteristics and the effect on gas content in Lower Palaeozoic Erathem of the eastern Sichuan Basin. Acta Geol Sin. 2014;88(7):1311-20 (in Chinese).

$\mathrm{Yu}$ ZG. Introduction to shale gas exploration and development in the Sichuan Basin. 973 Program (2012CB214700) Academic Exchange Symposium. In August, 2014. Lanzhou, China.

Zagorski WA, Bowman DC, Emery M, et al. An overview of some key factors controlling well productivity in core areas of the Appalachian Basin Marcellus Shale play. AAPG Annual convention and exhibition, Houston, Texas, USA, oral presentation, 2011

Zhang DW, Li YX, Zhang JC, et al. Nation-wide shale gas resource potential survey and assessment. Beijing: Geological Publishing House; 2012 (in Chinese). 
Zhou QH, Song N, Wang CZ, et al. Geological evaluation and exploration prospect of Huayuan shale gas block in Hunan Province. Nat Gas Geosci. 2014a;25(1):130-9 (in Chinese).

Zhou Q, Xiao XM, Tian H, et al. Modeling free gas content of the Lower Paleozoic shales in the Weiyuan area of the Sichuan Basin, China. Mar Pet Geol. 2014b;56:87-96.
Zou CN, Dong DZ, Wang SJ, et al. Geological characteristics, formation mechanism and resource potential of shale gas in China. Pet Explor Dev. 2010;37(6):641-53 (in Chinese).

Zou CN, Du JH, Xu CC, et al. Formation, distribution, resource potential and discovery of the Sinian-Cambrian giant gas field, Sichuan Basin, SW China. Pet Explor Dev. 2014;41(3):278-93 (in Chinese). 